\title{
Teachers in Conversation with Industry Scientists: Implications for STEM Education
}

\author{
Julia Morris $^{\mathrm{a}}$, Eileen Slater ${ }^{\mathrm{a}}$, Julie Boston ${ }^{\mathrm{a}}$, Michael Fitzgerald ${ }^{\mathrm{bc}}$, Geoff Lummis $^{\mathrm{a}}$ \\ Corressponding author: Julia Morris (j.morris@ecu.edu.au) \\ aSchool of Education, Edith Cowan University, Joondalup WA 6027, Australia \\ ${ }^{b}$ Las Cumbres Observatory, Goleta, CA 93111, United States of America \\ ${ }^{\mathrm{c} S}$ chool of Education, Deakin University, Burwood, VIC 3125, Australia
}

Keywords: STEM, industry, school partnerships, authentic science education

\begin{abstract}
Science, Technology, Engineering and Mathematics (STEM) is dominating industry as we become more technology-dependent and the workplace evolves. Consequently, engaging industry professionals in STEM education continues to be a priority in the Organisation for Economic Co-operation and Development (OECD) countries, as industry look to invest in students who will become future innovators. While industry partnerships with schools can help to drive authentic education in STEM, there needs to be a mutually respectful approach that capitalises on the expertise of each partner; that is, the deep discipline knowledge of industry and the pedagogical knowledge of educators. This research partnered industry scientists with early career science teachers to explore the implications of industry-school partnerships. Data were collected through interviews and focus groups with 15 participants. The qualitative data were inductively coded and triangulation occurred between different focus groups for dependability. The advice from industry scientists to educators focused on making science practical and authentic, while educators sought to engage industry partnerships to support the development of content knowledge and to overcome resourcing issues. In addition, the conversations between scientists and science educators illuminated a number of barriers to partnering, including what type of STEM careers to introduce to students and the appropriate age groups to target to ensure successful partnerships.
\end{abstract}

\section{Introduction}

The recent Optimising STEM industry-school partnerships: Inspiring Australia's next generation report outlines a decline in students' outcomes and engagement in STEM education while industry demands for STEM graduates increase (Education Council, 2018). Consequently, governments and industry are looking for opportunities to engage with the next generation through education in order to improve STEM capacity in students (Education Council, 2018; Gamse, Martinez, \& Bozzi, 2017). However, any engagement with education must acknowledge the pivotal role played by teachers. Hattie $(2009,2012)$ consistently reinforces that teachers significantly impact both students' attitudes towards learning, and learning itself. Consequently, interventions into STEM education need to meaningfully partner industry and educators to ensure that deep student learning occurs and that the type of learning is beneficial to the future workforce.

While these discussions are being had at senior levels of government and policy making, valuable insights into what teachers and industry would like from partnering can be found from engaging directly with individuals in these professions. This exploratory research sought to involve active industry scientists from within a large national STEM company and early career science teachers in a conversation about STEM industry-school partnerships. Specifically, the 
researchers sought to answer the questions: How do industry professionals and teachers view each other's role in improving STEM education? What are the possible implications of industry-school partnerships for STEM education in schools?

The aim of the dialogue was to 'bridge differing contexts and language' (Education Council, 2018 , p. 9) between industry and education, with each group sharing advice about how they thought STEM education could be supported through partnership. In response to the second research question, the participants began to share some of the challenges to establishing a STEM industry-school partnership. Extending this dialogue beyond policy is essential in providing practical strategies to enhance authentic STEM learning that are accessible and achievable for schools.

\section{Authentic STEM education}

Secondary students tend to resist traditional didactic teaching approaches to STEM Education, preferring authentic inquiry-based learning experiences (Tytler, 2007; Tytler, Osborne, Williams, Tytler, \& Cripps Clark, 2008). Authentic STEM opportunities aim to show the interconnectedness of science, technology, engineering and mathematics in everyday life (Akerson et al., 2018; Means et al., 2017; Parker, Pillai, \& Roschelle, 2016) and teach STEM concepts in context (Bybee, 2014). These learning experiences often use inquiry or problembased pedagogies that are student-centred and collaborative (Chiu, Price, \& Ovrahim, 2015). When STEM education requires active engagement and links content to real-world issues it is more likely to positively affect students' STEM dispositions and their interest in STEM careers (Christenson, Knezek, \& Tyler-Wood, 2015). Furthermore, using inquiry-based pedagogy has been shown to improve student engagement with STEM content along with the development of higher order thinking skills (Johnson, Peters-Burton, \& Moore, 2015).

However, teachers often report that there are barriers preventing them from undertaking authentic science in the classroom with their students (Burke et al., 2016; Fitzgerald et al., 2019; Tytler, et al., 2008). Not least of these are the significant barriers teachers may encounter in attempting to leverage networking opportunities with STEM initiatives and expertise, particularly if the teacher is to teach in rural or remote schools (e.g. Taylor \& Govan, 2017; Townsend et al., 2016) or in indigenous contexts (Donovan, 2018). As the first step, helping teachers to understand what authentic science actually is and how it can be implemented in the classroom is a priority (Lowrie, Downes, \& Leonard, 2017) and can be enhanced by collaboration between teachers, students and university academics (Lang et al., 2018). If teachers have not had an authentic experience themselves, they may lack a 'framework for action' that is responsive to their students' needs and the local community (Lowrie, et al., 2017). Integrating real-world experiences that are relatable for students is a core component of authentic STEM education (Morris et al., 2019; Tytler, et al., 2008).

\section{Industry engagement with STEM education}

Industry engagement with education is one strategy used to support teachers to deliver authentic STEM learning experiences. Internationally, engagement between industry and STEM educators is a priority (Gamse, et al., 2017) and has been shown to enhance learning outcomes (Bacharach, Manning, \& Goodman, 2010; Hirsch, Carpinelli, Kimmel, Rockland, \& Bloom, 2007; Karp, Gale, Lowe, Medina, \& Beutlich, 2010). Australia is no exception and in December 2015, the Education Council of Australia presented the National STEM School Education Strategy (2016-2026) so that STEM education activities could be coordinated to improve national outcomes (Education Council, 2015). With this mandate comes interventions to integrate industry with education. Rennie and Howitt (2009) found that mentoring on behalf 
of professionals involved in the Scientists in Schools ( $\mathrm{SiS}$ ) project inspired and motivated both parties, as teaching and learning with scientists enhanced the teachers' knowledge of scientific practices and the scientists enjoyed mentoring the students. An additional finding was that students understood scientists as real people working in interesting and rewarding careers, providing them with concrete experiences to aspire to long-term STEM careers (Rennie \& Howitt, 2009). The SiS project was extended into mathematics, and three strengths of the industry-school partnerships were found: (1) the collaborative nature of the one-on-one relationships between teacher and scientist or mathematician, (2) the flexibility of the model to adapt to meet local needs, and (3) sustainability that allows a longitudinal relationship between school and STEM professionals (Tytler et al., 2015).

While there are examples of positive industry engagement in education, there is more to be done. In exploring the Western Australian context (the context of this study), Hackling, Murcia, West and Anderson (2014) found that industry identified a lack of curriculum understanding as a barrier to participating in STEM education initiatives based on a lack of contemporary education approaches. The research underscored a need to address the disconnect between the wants, needs and possibilities of STEM teachers, industries and education service providers wanting to invest in STEM education (Hackling, et al., 2014). Furthermore, there needs to be acknowledgement that industry and STEM education partnerships exist across diverse contexts, including school-based programs, mentoring, excursions and extracurricular activities (Gamse, et al., 2017). Hackling et al. (2014) note that while extracurricular activities encourage positive engagement in STEM for participants (Stoeger et al., 2016) they do not provide all students with the opportunity to engage with authentic STEM education.

\section{Demands on teachers}

A strong relationship between industry and STEM educators depends on time to cultivate a positive working relationship that is mutually beneficial (Rennie \& Howitt, 2009; Tytler, et al., 2015). However, lack of time is a commonly cited issue for teachers (Fetherston \& Lummis, 2012; Le Cornu, 2013), leading to strain and burnout (Hultell, 2011). The dynamic nature of STEM advances requires that teachers have time to maintain current knowledge (Prinsley \& Johnston, 2015).

At a school and systemic level, there are broader issues of curriculum crowding and resourcing. The challenge of fitting STEM into an already crowded curriculum is significant (Lloyd, 2013), while also giving time for students to explore multiple sub-disciplines within each subject as well as interconnections between subjects (Timms, Moyle, Weldon, \& Mitchell, 2018). Other issues to delivering quality STEM education includes skilled educators and establishing a continuum of STEM learning across a students' school-life (Murphy, MacDonald, Danaia, \& Wang, 2018). Additional resourcing issues are access to specialist equipment and technologies used in authentic STEM contexts (Prinsley \& Johnston, 2015), as these have cost and training implications for schools.

\section{Methodology}

This paper presents the findings of the qualitative component of a case study conducted at one Australian university. While the overarching single case study (Yin, 2014) sought to explore how a partnership between industry and the university could support improved STEM content knowledge and self-efficacy for early career teachers, the qualitative data presented here address the two aforementioned research questions: How do industry professionals and 
teachers view each other's role in improving STEM education? What are the possible implications of industry-school partnerships for STEM education in schools?

\section{Participants and Research Context}

The research study took place in one Australian university. While the research team recognised that teacher development occurs over the span of a teachers' career, early career teachers formed the basis of the sample as these teachers are entering the workforce at a time when STEM education is a priority with the potential to impact on the next generation of secondary students. A total of 81 Western Australian early career teachers participated in the study, of which 11 participated in the interviews or focus groups. In addition to the early career teachers, four STEM industry professionals from the partner organisation participated in the study, including engineers and chemists. All four of these individuals participated in interviews or focus groups. The industry partner was a major STEM-driven organisation in Australia, who jointly funded the study with the university in order to invest in STEM education that would promote increased engagement between the organisation and local schools.

\section{Research Design}

Qualitative data were collected from the participants at the end of two professional learning days, co-hosted by the university and industry partner. Follow-up interviews were also conducted with individuals who wished to give further information but could not stay after the events. The focus groups lasted approximately 25 minutes each. Participants were given approximately 20 minutes to reflect on their STEM learning experiences individually before participating in the focus group. This allowed the participants to reflect on their internal voice prior to entering the group situation. The focus groups were situated at the conclusion of the day so that participants' experiences were recent and they could talk in depth about their lived experience over the course of the day.

The focus groups were semi-structured, allowing for each participant to share their views on a range of topics including: participation in the professional learning day, their perceptions of STEM education, their personal experiences of STEM education, and their perceptions of engaging in STEM industry-school partnerships.

\section{Analysis}

The focus group data were collected until saturation was reached to ensure sampling sufficiency (Janesick, 2000). The qualitative data were then analysed using inductive coding after an external transcription agency returned verbatim transcripts of recordings of the focus groups. One researcher initially coded the data using a thematic approach that generated codes based on a reading of the full dataset (Miles \& Huberman, 1994). The initial codes were then compared over time and multiple readings of the data. Triangulation occurred between investigators, as the research team worked both separately and collaboratively on the data collection and analyses. This approach allowed for triangulation between the different focus groups in order to ensure dependability (Cohen, Manion, \& Morrison, 2011).

\section{Findings}

\section{Advice from industry to early career STEM teachers}

The industry STEM professionals had two main pieces of advice for teachers to improve STEM education. The first related to making STEM an active learning experience through practical tasks, and the second was to explicitly show students how STEM relates to their everyday lives and futures. 
In discussing STEM education, the industry professionals focused on how STEM is engaging when it encompasses all the senses. They explained how they felt it was important for teachers to:

... inspire kids to really get in there and show them what Science does. Make it very visual; make it so they can touch, feel and experience Science firsthand before getting too far into all the technical stuff, so really engage them in the process of Science through the demonstrations.

All of the STEM professionals spoke about making science and STEM visual and stated that they could offer that support by working with schools and sharing their daily work experiences. In extending this discussion, they acknowledged how important it is to start with practical observations of STEM before moving into theoretical work:

You've got to make it exciting; you've got to give the kids something visual, something they can relate to because they won't relate to the theoretical, they won't relate to the mathematical; they will relate to something they can see, they relate to something they can do hands-on. If you can get them to actually physically do stuff and then explain to them the scientific process behind what they've just done, it'll sink in a lot more with the kids. If you just try to tell them about stuff, it won't go in.

The industry professionals also spoke about how STEM helps students to discover the world around them. Speaking of their own experience as a student, one industry professional remarked: 'I enjoyed all the practical lessons, Science in practice, to show how things actually worked in real life and I also enjoyed solving problems.'

While making learning an active experience of STEM was considered an important part of STEM education for the industry professionals, they also spoke about how STEM educators could do more to make STEM relatable for students and capitalise on their intrinsic motivations. They explained:

I guess in terms of being a teacher, whether it's a primary school teacher or a high school teacher, inspiring students to get into STEM, Science, whether it's Maths or whatever, to me showing them as many different things about as many different jobs as possible [is important] ... I guess [that] would speak to me because I simply would have had no idea what a cartographer did; I would have had no idea what a statistician did; I would have had no idea what a physicist did. I mean in some respects, I probably still don't have a full grasp understanding of that but in saying that, you never know what it is that will speak to one particular child.

The industry professionals also explained how they had different motivations for continuing their own STEM education. For example, one professional enjoyed understanding real-world science, but 'when it came to studying ... Mathematics I enjoyed getting correct answers ... so I enjoyed getting the right answer and also where those answers were related to real life, I found it much easier to learn.' The professionals emphasised that understanding what motivates students to achieve in each subject was important, and that these motivations might differ between the STEM subjects. 


\title{
Advice from early career teachers to STEM industries looking to partner
}

While the STEM professionals focussed on how STEM can be more engaging in schools through relatable content and active, authentic learning experiences, the early career teachers also felt there were ways that industry could meaningfully engage with education. Three main themes emerged from the early career teacher data: (1) that industry can support the development of discipline content knowledge, (2) that industry can support teachers with technical or equipment support, and (3) that industry partnerships can overcome resourcing issues for STEM education.

The early career science teachers in this sample were concerned about their content knowledge, as most had a deeper interest in one or more areas of science but did not feel they had deep content knowledge across all sub-disciplines of science. They discussed how industry professionals could help them to overcome this challenge, as they could seek advice from specialists in the field when teaching in a specific sub-discipline. A graduate teacher explained:

... any assistance that industry experts can provide teachers would just be fantastic because one of my observation from [practicum] ... was that there's no time. You do not have time to really go digging. If you can just ask someone a question you can get a lot of information just like that and that would be wonderful if there were people willing to answer technical questions.

One step beyond content knowledge was local knowledge, as teachers explained how STEM professionals working in local industries could support authentic learning experiences for students:

\begin{abstract}
Particularly with the local content [because] there's online physics forums which are really wonderful but with things like, you know, if there's somewhere we could run a field trip or [some way we could] go about getting our students some real examples of where this kind of chemistry is used locally, [it would be something] that they could actually relate it to.
\end{abstract}

In addition to deepening content knowledge, teachers also felt that industry professionals could offer support when they were using specialist equipment or technology in the classroom. Teachers explained that they had difficulty 'when it comes to trying to connect to those telescopes and things' and that any support from experts would be greatly appreciated as it would save time and build teachers' confidence in using the equipment. Furthermore, they explained how an ongoing partnership would allow for this support to occur over time; this was a distinct advantage over having a one-off professional learning experience:

They [PL providers] often give you opportunity to provide them with feedback but not necessarily ongoing support and things. Like in a day they want to know what you got out of it or how you rated it in terms of marketing and doing a better job of it. An industry partnership is long term.

The third theme from the teachers' responses was related to resourcing issues. The participant who spoke about taking students on field trips alluded to how industry-school partnerships could support teachers to undertake meaningful excursions and gain access to information on local STEM activities, and they also explicitly raised the issue of time to gather information 
themselves. However, the teachers also spoke about funding issues, and how it is challenging to provide authentic experiences for students.

\section{Implications for STEM industry-school partnerships}

While industry professionals and early career teachers spoke about how each other could promote the engagement of students in STEM through quality industry-school partnerships, both groups spoke about some of the challenges and implications when it came to establishing positive partnerships. Three main themes emerged from this discussion: (1) including what type of STEM careers and experiences to introduce to students, (2) the appropriate age groups to target to ensure successful partnerships and impact on student engagement, and (3) ensuring transparency of motives and goals for the partnership.

Presenting diversity in STEM was an issue raised by the industry professionals. While they spoke about presenting diversity in terms of motivating students, they also spoke about how some jobs might look boring to some students and that would be an issue when motivating students to sustain STEM education:

I guess chemical engineering and things like that, it's probably difficult to have a Year 11 [student] come through or even go and talk to a Year 11 [class], because if you look at what a chemical engineer does say on a day-to-day basis, you would show him twenty spreadsheets that you maintain ... it's probably just boring to them.

Part of the discussion on vocations also included pathways into STEM employment. The industry professionals explained that there were many options for students to become involved in a STEM career, not just through a university degree pathway. They shared how their company does 'quite a bit of work with a lot of the local communities, some colleges ... we've got a graduate program and a cadetship as well so for cadetships we take on students over summer for two months.' The industry professionals stressed that offering diverse experiences could occur through placements directly with industry beyond school hours.

Second, the teachers and industry professionals discussed the timing of STEM interventions in schools. While the teachers in the sample were secondary trained, they spoke about how it was essential for STEM education interventions to occur prior to senior secondary schooling:

It would have been great to see some more industry contact in the lower years
because by the time [students] get to the end of Year 10 most of them were going
off, they weren't continuing with the science. It was like ... because the
community was very strongly headed in the vocational training direction and
most of the kids had kind of been subconsciously channelled that way before
they even got to Year 11. So ... not many of them would stay on and do those
science, engineering, maths type subjects; they were very small classes and in
the younger years [it would be great] if they could see their local industry
workers leading the way, they might see the kinds of jobs that might be out there.

The final challenge discussed by teachers and professionals was the need to establish clear motives and goals for industry-school partnerships, especially when professional learning was involved. One teacher conveyed cynicism about the motives of industry-sponsored professional learning or partnership invitations: 


\begin{abstract}
I was part of [another university] for a while and they have a big industry program in Geology. I think, it can work very well, [but] I was probably a little bit cynical about the motives; it was a petroleum thing and there was a lot of money being pushed into how to dispose of carbon dioxide.
\end{abstract}

In addition to understanding each other's motives to engage in the partnership, teachers stressed the importance of developing mutually beneficial goals for the partnership, saying: 'there [can be] a very strong industry push towards what they wanted researchers to do, but with teaching it's probably not going to happen because you've got a set curriculum.' The teachers emphasised the importance of flexibility to align authentic research and field work experiences with the set curriculum to ensure that the partnership benefitted everyone involved.

\title{
Discussion
}

The qualitative data revealed a number of ways for teachers and STEM industry professionals to improve STEM learning in schools. The conversations emphasised authentic and active learning as a priority, with teachers highlighting opportunities for industry professionals to provide specialist content knowledge that was relevant to local issues. Furthermore, the teachers identified industry professionals as support providers when engaging with specialist equipment or technology that was beyond the expertise of the teacher. The emphasis placed on authentic inquiry-based learning by the industry professionals as the type of learning that was most engaging for them is consistent with current students' perceptions of engaging science education (Tytler, 2007; Tytler, et al., 2008). Similarly, the industry professionals raised the importance of making connections to local knowledge and activities as this makes learning relevant for students, showing them the interconnectedness of STEM in the context of everyday life (Akerson, et al., 2018; Bybee, 2014; Means, et al., 2017; Parker, et al., 2016).

While the benefits of authentic, inquiry-based learning linked to students' everyday experiences include more positive STEM dispositions and sustained interest in STEM learning and careers (Christenson, et al., 2015), teachers explained some of the barriers to engaging in STEM. The early career teachers noted demands on time and resourcing issues as core issues, similar to the literature (Buchanan, et al., 2013; Fetherston \& Lummis, 2012; Le Cornu, 2013). These issues are heightened in STEM, as the dynamic nature of STEM advancements requires teachers to continually be revising their content knowledge and practices (Prinsley \& Johnston, 2015). However, industry professionals could support teachers to provide a 'framework for action' that is responsive to student and community needs (Lowrie, et al., 2017, p. 22). Industry professionals spoke about supporting teachers through demonstrations of work, and teachers conveyed similar wishes when discussing how industry professionals could offer specialist support in content knowledge and STEM practices when teachers did not feel confident in the area. Through this conversation, the industry professionals and teachers began to explain a potential for partnership that has mutual benefit, whereby industry professionals could provide a layer of support beyond their immediate school context resulting in reciprocal mentoring benefits (Tytler, et al., 2015).

The second piece of advice from STEM professionals related to motivating students to engage in STEM. From their own learning experiences, motivation was also linked back to authentic, real-world issues with a particular emphasis on problem solving. For some of the professionals there was also motivation in getting the answer right, broadening their understanding of STEM concepts. For teachers, this discussion extended ideas about having industry professionals engage with students. Similar to Rennie and Howitt (2009), both industry professionals and 
teachers were inspired and motivated by the thought of having industry engage directly with school students. There was discussion about how motivation can be enhanced through exposing students to diverse STEM careers and specialisations, so that students would come to understand STEM professionals as real people working in interesting and rewarding careers (Rennie \& Howitt, 2009).

The initial discussions about improving STEM education began to touch on a number of implications for how STEM industry-school partnerships could be enacted in schools. The two primary themes were needing to enter a partnership with time to plan experiences towards shared goals, and to intervene early in students' school-life so that they can be afforded a range of STEM experiences. In terms of partnering, it was evident that there needed to be effective integration of STEM professionals' content knowledge and experience with teachers' curriculum and assessment requirements, a view shared by Hackling et al. (2014). In achieving this, time is needed to plan shared learning experiences that are flexible to the needs of both parties (Rennie \& Howitt, 2009; Tytler, et al., 2015) and acknowledge the crowded curriculum demands of contemporary schools (Lloyd, 2013).

The second theme was about when and how to intervene in STEM education. Both teachers and industry professionals noted that education often leaves it too late to show students a range of careers in STEM, and this negatively effects senior school enrolment of students in STEM subjects (Education Council, 2018). Industry professionals explained how students will not know what they want to pursue or are interested in if they don't know the range of specialist fields that exist and they've never experienced them. Consequently, industry and schools can partner to give students experience in a range of STEM activities that begin to illuminate potential pathways in STEM and this could be done both within and beyond school activities. The industry professionals who participated in the research highlighted opportunities for students to engage with industry through cadetship programs, raising the importance of alternative pathways into STEM careers beyond university study and in addition to schoolbased experiences. Similar to the evaluation on the Scientists and Mathematicians in Schools project (Tytler, et al., 2015), the industry professionals and teachers in this study discussed partnerships as longitudinal relationships that would allow for diverse experiences to be offered over time. This type of partnership promotes the exploration of multiple sub-disciplines within each STEM subject as well as the interconnections between subjects (Timms, et al., 2018). Facilitating further conversations and research between school teachers, industry and the university academics that are tasked to prepare teachers to further uncover ways and means to engage STEM education with authentic STEM practices will be an indispensable aid to the field. In particular, bringing in the knowledge of in-service teachers and their expertise and experience and a wider sample of potential partner industries would be invaluable in this endeavour.

\section{Conclusion}

This small-scale exploratory study brought together STEM industry professionals and early career teachers to discuss STEM education and how industry-school partnerships could promote engagement in STEM. While industry-school partnerships have proved successful in the past (Rennie \& Howitt, 2009; Tytler, et al., 2015), it is essential that the conversation between industry and education practitioners remains open. The participants in this study all advocated for sustainable, longitudinal relationships between industry and schools. STEM industry professionals were viewed as a reliable source of specialist content knowledge and skills that could support authentic STEM learning. Importantly, having STEM professionals 
engage directly with students was emphasised as being beneficial to both teachers' professional learning and in motivating students' engagement with authentic learning experiences. An interesting finding from the industry professionals was the diversity of experiences they could offer students, including cadetship pathways that would support students' direct engagement with STEM industries in addition to school-based learning experiences. However, it is important that industry-school partnerships are carefully managed so that they capitalise on each parties' strengths, and are flexible to each parties' needs. With open communication between education and industry there is potential to introduce diverse, authentic STEM learning experiences for students that raise STEM engagement and promote sustained engagement with future-focussed industries.

\section{Acknowledgements}

Dr. Michael Fitzgerald is the recipient of an Australian Research Council Discovery Early Career Award (project number DE180100682) funded by the Australian Government. This project was undertaken with ethics approval from the ECU Human Research Ethics Committee (HREC) number 16523.

\section{References}

Akerson, V. L., Burgess, A., Gerber, A., Guo, M., Khan, T. A., \& Newman, S. (2018). Disentangling the meaning of STEM: Implications for science education and science teacher education. Journal of Science Teacher Education, 29(1), pp. 1-18.

Bacharach, E. R., Manning, C. F., \& Goodman, I. F. (2010). SAE AWIM evaluation. Cambridge, MA: http://www.awim.org/about/reportcard/executivesummary.pdf

Buchanan, J., Prescott, A., Schuck, S., Arbusson, P., Burke, P., \& Louviere, J. (2013). Teacher retention and attrition: Views of early career teachers. Australian Journal of Teacher Education, 38(3), pp. 112-129. doi:10.14221/ajte.2013v38n3.9

Burke, P. F., Aubusson, P., Schuck, S., Palmer, T., Pressick-Kilborn, K., \& Ng, W. (2016). Barriers to the effective teaching of primary science and technology. Sydney, Australia: Association of Independent Schools of NSW. http://ow.ly/cVWI30c7gwj

Bybee, R. W. (2014). NGSS and the next generation of science teachers. Journal of Science Teacher Education, 25(2), pp. 211-221. doi:10.1007/s10972-014-9381-4

Chiu, A., Price, C. A., \& Ovrahim, E. (2015) Supporting elementary and middle school STEM education at the whole school level: A review of the literature. Paper presented at the NARST 2015 Annual Conference, Chicago, IL.

Christenson, R., Knezek, G., \& Tyler-Wood, T. (2015). Alignment of hands-on STEM engagement activities with positive STEM dispositions in secondary school students. Journal of Science Education and Technology, 24(6), pp. 898-909.

Cohen, L., Manion, L., \& Morrison, K. (2011). Research methods in education (7th ed.) New York, NY: Routledge.

Donovan, M. (2018). Local Collaboration to Grow the Seeds of STEM Investment from School and Beyond, International Journal of Innovation in Science and Mathematics Education. 26(2), pp. 3-13

Education Council. (2015). National STEM school education strategy: A comprehensive plan for science, technology, engineering and mathematics education in Australia. Canberra, Australia: http://www.educationcouncil.edu.au/site/DefaultSite/filesystem/documents/National STEM School Education Strategy.pdf

Education Council. (2018). Optimising STEM industry-school partnerships: Inspiring Australia's next generation. Carlton, Australia: Education Services Australia. http://www.educationcouncil.edu.au/site/DefaultSite/filesystem/documents/Reports and publications/Publications/Optimising STEM Industry-School Partnerships - Final Report.pdf

Fetherston, T., \& Lummis, G. (2012). Why Western Australian secondary teachers resign. Australian Journal of Teacher Education, 37(4), 1.

Fitzgerald, M.T., Danaia, L., McKinnon, D., (2019). Barriers inhibiting inquiry-based science teaching and potential solutions: Perceptions of positively inclined early adopters. Research in Science Education, 49(2), pp. $543-566$

Gamse, B. C., Martinez, A., \& Bozzi, L. (2017). Calling STEM experts: How can experts contribute to students' increased STEM engagement? International Journal of Science Education, Part B, 7(1), pp. 31-59. doi:http://www.tandfonline.com/action/showCitFormats?doi=10.1080/21548455.2016.1173262 
Hackling, M., Murcia, K., West, J., \& Anderson, K. (2014). Optimising STEM education in WA schools. Perth, Australia: Edith Cowan Institute for Education Research. https://www.ecu.edu.au/_data/assets/pdf_file/0004/627133/Optimising-STEM-education-in-WA-FullResearch-Report.pdf

Hattie, J. (2009). Visible learning: A synthesis of over 800 meta-analyses relating to achievement Oxon, England: Routledge.

Hattie, J. (2012). Visible learning for teachers: Maximizing impact on learning London, England: Routledge.

Hirsch, L., Carpinelli, J., Kimmel, H., Rockland, R., \& Bloom, J. (2007) The differential effects of female only vs. co-ed enrichment programs on middle schools students' attitudes toward science, mathematics, and engineering. Paper presented at the American Society for Engineering Education Annual Conference \& Exposition, Milwaukee, WI. http://www.icee.usm.edu/icee/conferences/asee2007/papers392_THE_DIFFERENTIAL_EFFECTS_OF_FE MALE_ONLY_.pdf

Hultell, D. (2011). Lost in translation? A study of newly graduated teachers' experiences during the initial period of employment Stockholm, Sweden: Karolinska Institute.

Janesick, V. J. (2000). The choreography of qualitative research design: Minuets, improvisations and crystallization. In N. K. Denzin \& Y. S. Lincoln (Eds.), Handbook of Qualitative Research (2nd ed., pp. 379-400). Thousand Oaks, CA: Sage Publications.

Johnson, C. C., Peters-Burton, E. E., \& Moore, T. J. (2015). STEM road map: A framework for integrated STEM education London, England: Taylor and Francis.

Karp, T., Gale, R., Lowe, L. A., Medina, V., \& Beutlich, R. (2010). Generation NXT: Building young engineers with LEGOs. IEEE Transactions on Education, 53(1), pp. 80-87.

Lang, C., Powell, G., Ibrahim, F., Moore, N. (2018). Connecting Teachers, Students and Pre-service Teachers to Improve STEM Pathways in Schools, International Journal of Innovation in Science and Mathematics Education, 26(8), pp 45-66

Le Cornu, R. (2013). Building early career teacher resilience: The role of relationships. Australian Journal of Teacher Education, 38(4), pp. 1-16.

Lloyd, M. M. (2013). Troubled times in Australian teacher education: 2012-2013. Sydney, Australia: Office for Learning and Teaching. https://eprints.qut.edu.au/64946/

Lowrie, T., Downes, N., \& Leonard, S. (2017). STEM education for all young Australians: A bright spots STEM learning hub foundation paper, for SVA, in partnership with Samsung. Canberra, Australia: University of Canberra STEM Education Research Centre. https://www.socialventures.com.au/assets/STEM-educationfor-all-young-Australians-Smaller.pdf

Means, B., Wang, H., Wei, X., Lynch, S., Peters, V., Young, V., \& Allen, C. (2017). Expanding STEM opportunities through inclusive STEM-focused high schools. Science Education, 101(5), pp. 681-715.

Miles, M., \& Huberman, A. (1994). An expanded sourcebook: Qualitative data analysis (2nd ed.) London, England: Sage Publications.

Morris, J., Slater, E., Fitzgerald, M.T., Lummis, G.W., van Etten, E. (2019). Using Local Rural Knowledge to Enhance STEM Learning for Gifted and Talented Students in Australia. Research in Science Education, 1 19

Murphy, S., MacDonald, A., Danaia, L., \& Wang, C. (2018). An analysis of Australian STEM education strategies. Policy Futures in Education. doi:10.1177/1478210318774190

Parker, C. E., Pillai, S., \& Roschelle, J. (2016). Next generation STEM learning for all: A report from the NSF supported forum. Waltham, MA: Education Development Center.

Prinsley, R., \& Johnston, E. (2015). Transforming STEM teaching in Australian primary schools: Everybody's business. Canberra, Australia: Office of the Chief Scientist. https://www.chiefscientist.gov.au/wp.../Transforming-STEM-teaching_FINAL.pdf

Rennie, L. J., \& Howitt, C. (2009). "Science has changed my life!” Evaluation of the scientists in schools project 2008-2009. Dickson, Australia: CSIRO. https://www.csiro.au/ /media/Educationmedia/.../SiSEvaluationReport-2008-2009.pdf

Schwandt, T. A. (2000). Three epistemological stances for qualitative inquiry: Interpretivism, hermeneutics, and social constructionism. In N. K. Denzin \& Y. S. Lincoln (Eds.), Handbook of qualitative research. Thousand Oaks, CA: Sage Publications.

Stoeger, H., Schirner, S., Laemmle, L., Obergriesser, S., Heilemann, M., \& Ziegler, A. (2016). A contextual perspective on talented female participants and their development in extracurricular STEM programs. Annals of the New York Academy of Sciences, 1377(1), pp. 53-66. doi:10.1111/nyas.13116

Taylor, D., Govan, B. (2017). STEM Outreach in Northern Queensland: The Importance of Providing Professional Development and Networking Opportunities to Educators. International Journal of Innovation in Science and Mathematics Education, 25(5), pp 57-68. 
Timms, M., Moyle, K., Weldon, P., \& Mitchell, P. (2018). Challenges in STEM learning in Australian schools: Literature and policy review. Camberwell, Australia: Australian Council for Educational Research. https://research.acer.edu.au/cgi/viewcontent.cgi?article=1007\&context=policyinsights

Townsend, A., McKinnon, D.H., Fitzgerald, M.T., Lummis, G., Morris, J. (2016) Educative Curricula and PCK development driven by STEM professional learning in rural and remote schools: A longitudinal Type IV case study. International Journal of Innovation in Science and Mathematics Education, Going Rural Special Edition, 24(4), 1-17

Tytler, R. (2007). Re-imagining science education engaging students in science for Australia's future. Australian Education Review, 51, pp. 1-77.

Tytler, R., Osborne, J. F., Williams, G., Tytler, K., \& Cripps Clark, J. (2008). Opening up pathways: Engagement in STEM across the primary-secondary school transition. A review of the literature concerning supports and barriers to Science, Technology, Engineering and Mathematics engagement at primarysecondary transition. Canberra, Australia: Australian Department of Education Employment and Workplace Relations.

Tytler, R., Symington, D., Williams, G., White, P., Campbell, C., Chittleborough, G., .. . Dziadkiewicz, N. (2015). Building productive partnerships for STEM education: Evaluating the model and outcomes of the scientists and mathematicians in schools program 2015. Burwood, Australia: Deakin University. https://www.csiro.au/en/Education/Programs/STEM-Professionals-in-Schools/How-the-programworks/Program-evaluation

Yin, R. K. (2014). Case study research: Design and methods (5th ed.) Thousand Oaks, CA: Sage Publications. 